\title{
WHEAT PRODUCTIVITY AS AFFECTED BY VARIETIES, NITROGEN, ORGANIC AND BIO-FERTILIZERS UNDER NEW RECLAIMED SOIL CONDITION.
}

Abd El-Samie, F.S., Megawer, E.A., Ismail, S.K.A., and Hafiz, A.H.R., Agronomy Department, Faculty of Agriculture, Fayoum University, El -Fayoum,

\section{ABSTRACT} Egypt

Two field experiments were carried out in the Experimental Farm , of the Faculty of Agriculture , Fayoum University on Sandy Loam soil during 2011 / 2012 and 2012 / 2013 seasons to study the effects of two organic manure levels i.e. (15 and $30 \mathrm{~m}^{3} /$ fed.), biofertilizer (Azotobacter who was inoculation the seeds) and three levels of nitrogen fertilizer .[100\% (75 kg N / fed. ) \& $50 \%$ (37.5 kg N / fed.) and $25 \%$ (18.75 kg N / fed.) ] of Urea ( $46 \% \mathrm{~N})$ and their combinations on productivity of two wheat cultivars i.e. (Sakha $93\left(\mathrm{~V}_{1}\right)$ \&Sakha 94 (v2)).The treatments were set in Randomized Complete Block Design (RCBD) in factorial arrangement with three replications .

Significant effect for wheat varieties were obtained on plant height $(\mathrm{cm})$, in the $1^{\text {st }}$ season and on total protein percentage in both seasons but was insignificantly on other traits.The superiority was for Sakha 94 in most characters .

Fertilizer treatments was significantly effect on all traits in both season except plant height, number of spike / plant ,1000-grain weight in second season and harvest index\% in first season. $\mathrm{F}_{3} \quad\left(30 \mathrm{~m}^{3} / \mathrm{fed}\right.$. organic manure + bio - fertilizer $+50 \%(37.5 \mathrm{~kg} \mathrm{~N} /$ fed.) treatment gave the highest values followed by $\mathrm{F}_{4}\left(30 \mathrm{~m}^{3} / \mathrm{fed}\right.$. organic manure + bio - fertilizer $+25 \%(18.75 \mathrm{~kg} \mathrm{~N} /$ fed. $))$ or $\mathrm{F}_{5}\left(30 \mathrm{~m}^{3} /\right.$ fed. organic manure $+50 \%(37.5 \mathrm{~kg} \mathrm{~N} /$ fed. $))$ treatments .

Interaction between varieties and fertilizer treatments was significantly effect on number of spike / plant and weight of grains / spike in both seasons and on grain yield (ton / fed.) and total protein $(\%)$ in $1^{\text {st }}$ and number of grains / spike in second season only but was insignificantly on plant height $(\mathrm{cm}), 1000$-grain weight, and harvest index $(\%)$ in both seasons .

Results of stepwise regression revealed that both the harvest index, 1000 grains weight, number of grains/ spike and plant height were causes high grains yield genotypes in wheat programs.

By using organic fertilizer and / or bio-fertilizer with half dose of mineral fertilizer it could be increased in plant growth and yield . Besides, using bio-fertilizers that contain different microbial strains had led to decrease in the use of chemical fertilizers and had provided height products free of harmful agrochemicals for human safety.

Fayoum J. Agric. Res. \& Dev., Vol. 31, No.2, July, 2017 
Abd El-Samie, F.S.,

Key word: Wheat, Organic manure, Bio-fertilizer, Nitrogen fertilizer, Varieties, Stepwise.

\section{INTRODUCTION}

Wheat (Triticum aestivum L.) is one of the most important cereal crops in Egypt . Nowadays, major efforts have been made to minimize the gap between production and consumption. Production of wheat grains in Egypt is not enough to achieve self-sufficiency due to the high consumption rate per capita and high increasing rate in population every year, its cultivated area is about 3.1 milion feddan. The local production is about 9.5 million ton however; it covers less than $60 \%$ of local consumption (FAO, 2013).

Wheat is one of the cheapest sources of carbohydrate and also contains a considerable amount of protein, minerals and vitamins.

There are many factors, which can help to increase wheat production of which the use modern varieties and judicious fertilization are important. It is well recognized that crop productivity depends on adequate plant nutrient and organic matter content of the soil.

Manure play an important role in improving physical, chemical and biological properties of soils.

Due to low nutrient content and slow acting nature, organic manure alone may fail to meet the high nutritional requirements of crops.

Some of the plant nutrients, when added to the soil in inorganic form, have low efficiency as compared with the effect of the same nutrients applied along with organic manure.

Thus, organic manure reduce the application rate of chemical fertilizers and also help to solve the problem of micro - nutrient deficiency in the soil.

Azotobacter is a heterotrophic, aerobic micro-organism, fixing nitrogen as non-symbiotix which is a good source of bio-fertilizer to improve the growth and yield of cereals and many other crops.

Fertilizer $\mathrm{N}$ and organic $\mathrm{N}$ have their own merits and demerits and the drawbacks associated with either sources of these plant nutrients are often overcome when these are mixed in judicious combinations .

In additional, stepwise regression is a method that is used to estimate the value of a quantitative variable regarding its relation with one or some other quantitative variables. This relation is such that it is possible to predict other changes using one variable. Many investigators have used this technique on wheat such as Mohamed (1999), Pržulj and Momcilovic (2011), Soleymanifard et al. (2012).

The objective of the present investigation was to study the effect of mineral ( urea), organic $\mathrm{N}$ and bio-fertilizer ( Azotobacter) applied alone and in various combinations on productivity for two wheat cultivars, so as to select the most appropriate combinations doses of these fertilizers in wheat production saving as much fertilizer $\mathrm{N}$ as possible and to determine effective traits on yield under newly reclaimed soil.

Fayoum J. Agric. Res. \& Dev., Vol. 31, No.2, July, 2017 
WHEAT PRODUCTIVITY AS AFFECTED BY.

MATERIALS AND METHODS

Experimental Procedures. Two field experiments were conducted at the Experimental Farm of the Faculty of Agriculture Fayoum, University in Demo Farm, during 2011/2012 and 2012/2013 seasons. The experiments were carried out to study the effect of two organic manure and bio-fertilizer as a total or partial replacement of nitrogen fertilizer under new reclaimed soil conditions in two bread wheat cultivars. A factorial experiment based on completely randomized design with three replications was used. The studied factors were two bread wheat varieties i.e. Sakha $93\left(\mathrm{~V}_{1}\right)$ and Sakha $94\left(\mathrm{~V}_{2}\right)$ were obtained from Field Crop Research Institute, Agricultural Research Center, Giza, Egypt, and Seven different combination of fertilizer treatments between organic manure, mineral and bio-fertilizer (Azotobacter was inoculated the seeds). The combination treatments were Control $=75 \mathrm{~kg} \mathrm{~N} / \mathrm{fed}$ $\left(F_{1}\right), 30 \mathrm{~m}^{3} / \mathrm{fed}$ organic manure + bio-fertilizer $\left(\mathrm{F}_{2}\right), 30 \mathrm{~m}^{3} / \mathrm{fed}$ organic manure + bio-fertilizer $+37.5 \mathrm{~kg} \mathrm{~N} / \mathrm{fed} .\left(\mathrm{F}_{3}\right), 30 \mathrm{~m}^{3} / \mathrm{fed}$ organic manure + bio-fertilizer $+18.75 \mathrm{~kg} \mathrm{~N} /$ fed. $\left(\mathrm{F}_{4}\right), 30 \mathrm{~m}^{3} / \mathrm{fed}$ organic manure $+37.5 \mathrm{~kg} \mathrm{~N} / \mathrm{fed} .\left(\mathrm{F}_{5}\right)$, $15 \mathrm{~m}^{3} / \mathrm{fed}$ organic manure $+37.5 \mathrm{~kg} \mathrm{~N} / \mathrm{fed} .\left(\mathrm{F}_{6}\right)$ and bio-fertilizer $+37.5 \mathrm{~kg}$ $\mathrm{N} / \mathrm{fed}\left(\mathrm{F}_{7}\right)$. A Randomized complete block design in factorial arrangement with three replications was used. The size of each plot was $10.5 \mathrm{~m}^{2}(3.5 \mathrm{~m}$ long and $3.0 \mathrm{~m}$ wide).

Agronomic Traits. Plant height, number of spike/plant, number of grains/spike, Weight of grains/spike, 1000-grain weight, Harvest index, grain yield/fed. and protein percentage (Pro.\%) were determined after the plants were harvested. protein percentage measured by near infrared analyzer according to Granland and Zimmerman (1975).

Statistical Analysis. All the data collected of wheat at the two seasons were statistically analyzed according to the procedures cut lined by Snedecor and Cochran (1980). To compare treatment means, LSD at $5 \%$ level of significance was used according to Stell and Torrie (1960). The stepwise regression analysis was also carried out for the data obtained to test the significance of the independent variables affecting the grain yield.

\section{RESULTS AND DISCUSSION}

\section{Effect of varieties}

The data illustrated in table (1) show the effect of wheat varieties and treatments of fertilizer. Plant height was significantly in first season only and protein percentage was significantly in both seasons, whereas, there was no significant effect of varieties on other studied traits in both seasons. Sakha 94 variety superiority on Sakha 93 for all studied traits except for 1000-grain weight in both seasons and harvest index and grain yield in $2^{\text {nd }}$ season. This may be due to the differences in genetic construction, these results are in generally agreement with those obtained by, Ali et al (2004), Badran (2009), Mattas et al (2011), Woyema et al (2012), Zaki et al (2012), Abd El-Razek and El-Sheshtawy (2013), Bithy (2014), Radwan et al (2014), Lemma

Fayoum J. Agric. Res. \& Dev., Vol. 31, No.2, July, 2017 
Abd El-Samie, F.S., $\quad 72$

(2015), Mehasen et al (2015), Abo-Remaila and Abo El-Enin (2016) and Babar et al (2016).

Effect of treatments of fertilizer:

The results presented in Table 1, clearly, indicated that there were significant on all studied traits in both seasons except plant height, number of spike/plant and 1000-grains weight in the $1^{\text {st }}$ season and harvest index in the $2^{\text {nd }}$ season. The tallest plants were obtained from $F_{3}$ treatment, and $F_{4}$ treatment followed by $\mathrm{F}_{2}$ treatment gave the largest number of spike/plant (5.17 and 5.00, respectively). The two treatments $F_{5}$ and $F_{4}$ gave higher number of grains per spike $(63.67,63.33)$ in $1^{\text {st }}$ season and $(68.67,68.50)$ in $2^{\text {nd }}$ season and weight of grains/spike in the second season $(3.53,3.17)$ respectively, also $F_{7}$ and $F_{5}$ followed by $F_{3}$ treatment (in $1^{\text {st }}$ season) gave higher weight of grains per spike than the other fertilizer treatments. $F_{3}$ treatment alone gave higher weight for 1000-weight (48.03g), grains yield/fed (2.23 and 2.59t in $1^{\text {st }}$ and $2^{\text {nd }}$ seasons, respectively) and high percentage for harvest index $\left(44.90 \%\right.$ in $2^{\text {nd }}$ season) and protein percentage (14.38 and $14.79 \%$ in $1^{\text {st }}$ and $2^{\text {nd }}$ seasons, respectively) than the other fertilizer treatments. It's may be due to the organic manure, bio-fertilizer and nitrogen fertilizer increased mineral contents of soil and adjusted physical characters of soil to good conditions, this finding are conceded with those obtained by Abraham and Lal (2004), El Gizawy (2009), Shah et al (2010), Hammad et al (2011), Agamy et al (2012), Mohammed et al (2012), Zaki et al (2012), El-Nady and Borham (2013) and Esmailpour et al (2013).

Effect of the interaction:

The interaction between wheat varieties and fertilizer treatments in table (2) was significant in 2011/2012 season only in grain yield (two varieties Sakha 93 and Sakha 94 remained at par under $F_{3}$ treatment gave highest yield per feddan) and in total protein ( \%) (Sakha 94 variety $\left(\mathrm{V}_{2}\right)$ when treated by $\mathrm{F}_{3}$ treatment gave the highest grain protein percentage ) and significant in two seasons in number of spike/plant and weight of grains / spike, the highest number of spike/plant resulted from the variety Sakha 93( $\left.V_{1}\right)$ when fertilized with $\mathrm{F}_{2}$ treatment in first season and Sakha 94( V2 ) when fertilized with F5 or f4 treatment in second season, while,v1f1 interaction gave the highest weight of grains / spike in first season also the same variety followed by v2 under f5 treatment gave the highest weight in second season. On the other hand number of grains/spike was significant in the second season only, v1f5 and v2f4 interaction gave largest number $(70.33,69.33$ ) respectively. But was not significant in both seasons in 1000 - grains weight $(\mathrm{g})$ and harvest index \%, this finding are conceded with those obtained by Ali et al( 2004 ), Woyema et al ( 2012 ), Zaki et al ( 2012 ), Abd El - Razek and El Sheshtawy (2013), Bithy ( 2014 ) and Radwan et al( 2014 ).

Fayoum J. Agric. Res. \& Dev., Vol. 31, No.2, July, 2017 
WHEAT PRODUCTIVITY AS AFFECTED BY.

Table (1): Effect of wheat varieties and treatments of fertilizer on yield and some yield traits in two seasons $(2011 / 2012-2012 / 2013)$.

\begin{tabular}{|c|c|c|c|c|c|c|c|c|c|c|c|c|c|c|c|c|}
\hline \multirow[t]{2}{*}{ Treatments } & \multicolumn{2}{|c|}{$\begin{array}{l}\text { plant } \\
\text { height } \\
(\mathbf{c m})\end{array}$} & \multicolumn{2}{|c|}{$\begin{array}{c}\text { No. of } \\
\text { spike/plant }\end{array}$} & \multicolumn{2}{|c|}{$\begin{array}{c}\text { No. of } \\
\text { grains /spike }\end{array}$} & \multicolumn{2}{|c|}{$\begin{array}{c}\text { Weight of } \\
\text { grains /spike }\end{array}$} & \multicolumn{2}{|c|}{$\begin{array}{c}\text { 1000-grains } \\
\text { weight }(\mathrm{g})\end{array}$} & \multicolumn{2}{|c|}{$\begin{array}{c}\text { Harvest } \\
\text { index }(\%)\end{array}$} & \multicolumn{2}{|c|}{$\begin{array}{c}\text { Grain yield } \\
\text { (ton/fed.) }\end{array}$} & \multicolumn{2}{|c|}{ Protein \% } \\
\hline & $1^{\text {st }}$ & $2^{\text {nd }}$ & $1^{\text {st }}$ & $2^{\text {nd }}$ & $1^{\text {st }}$ & $2^{\text {nd }}$ & $1^{\mathrm{st}}$ & $2^{\text {nd }}$ & $1^{\text {st }}$ & $2^{\text {nd }}$ & $1^{\text {st }}$ & $2^{\text {nd }}$ & $1^{\text {st }}$ & $2^{\text {nd }}$ & $1^{\text {st }}$ & $2^{\text {nd }}$ \\
\hline \multicolumn{17}{|c|}{ Varieties (V) } \\
\hline $\begin{array}{l}V_{1}=\text { Sakha93 } \\
\end{array}$ & \begin{tabular}{|l|}
77.19 \\
\end{tabular} & 85.95 & 4.62 & 5.10 & 59.76 & 63.90 & 2.93 & 3.06 & 46.45 & 47.01 & 36.97 & 43.95 & 1.76 & 2.44 & 11.51 & 11.71 \\
\hline $\mathrm{V}_{2}=$ Sakha94 & 84.48 & 87.29 & 4.81 & 5.19 & \begin{tabular}{|l|}
59.71 \\
\end{tabular} & 64.24 & 3.02 & 3.09 & 45.68 & 46.33 & 37.12 & 42.72 & 1.89 & 2.32 & 11.89 & 12.02 \\
\hline $\mathbf{L S D}_{0.05}$ for $\mathrm{V}$ & 3.99 & n.s & n.s & n.s & n.s & $\mathrm{n} . \mathrm{s}$ & n.s & n.s & n.s & n.s & n.s & n.s & n.s & n.s & 0.21 & 0.22 \\
\hline \multicolumn{17}{|c|}{ Fertilizer ( F ) } \\
\hline$\overline{F_{1}}$ & 82.67 & 85.67 & 4.33 & 5.17 & 60.50 & 62.83 & 3.10 & 2.98 & 46.78 & 47.22 & 36.19 & 45.60 & 1.92 & 2.59 & 7.53 & 7.53 \\
\hline $\mathbf{F}_{2}$ & 75.67 & 81.67 & 5.00 & 5.33 & 50.67 & 62.00 & 2.80 & 2.83 & 46.33 & 47.08 & 36.33 & 41.27 & 1.97 & 2.31 & 11.02 & 11.03 \\
\hline$F_{3}$ & 85.67 & 88.83 & 4.50 & 5.00 & \begin{tabular}{|l|}
59.67 \\
\end{tabular} & 61.00 & 3.10 & 3.07 & 48.03 & 48.52 & 38.46 & 44.90 & 2.23 & 2.59 & 14.38 & 14.79 \\
\hline $\mathbf{F}_{4}$ & 81.83 & 89.33 & 5.17 & 5.50 & 63.33 & 68.50 & 2.78 & 3.17 & 45.55 & 46.13 & 37.29 & 45.78 & 1.68 & 2.45 & 14.15 & 14.42 \\
\hline $\mathbf{F}_{5}$ & 83.33 & 88.83 & 4.67 & 5.33 & 63.67 & 68.67 & 3.13 & 3.53 & 44.85 & 45.58 & 35.30 & 40.39 & 1.75 & 1.93 & 12.53 & 12.78 \\
\hline$F_{6}$ & 80.67 & 87.33 & 4.50 & 4.83 & \begin{tabular}{|l|}
59.67 \\
\end{tabular} & 63.50 & 2.73 & 2.92 & 44.75 & 45.57 & 37.59 & 40.05 & 1.62 & 2.22 & 9.21 & 9.39 \\
\hline $\mathbf{F}_{7}$ & 76.00 & \begin{tabular}{|l|}
84.67 \\
\end{tabular} & 4.83 & 4.83 & 60.67 & 62.00 & 3.18 & 3.02 & 46.15 & 46.60 & 38.15 & 45.34 & 1.59 & 2.56 & 13.07 & 13.10 \\
\hline $\mathrm{LSD}_{0.05}$ for $\mathrm{F}$ & \begin{tabular}{|l|}
3.44 \\
\end{tabular} & n.s & 0.58 & n.s & 2.49 & 3.03 & 0.209 & 0.220 & 2.01 & n.s & n.s & 2.80 & 0.31 & 0.26 & 0.40 & 0.41 \\
\hline
\end{tabular}

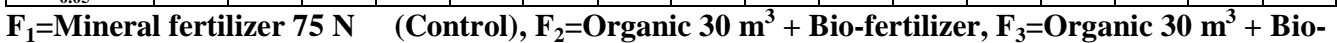
fertilizer + 37.5 $\mathrm{N}, \mathrm{F}_{4}=$ Organic $30 \mathrm{~m}^{3}+$ Bio-fertilizer $+18.75 \mathrm{~N}, \mathrm{~F}_{5}=$ Organic $30 \mathrm{~m}^{3}+37.5 \mathrm{~N}^{3}$ $F_{6}=$ Organic $15 \mathrm{~m}^{3}+37.5 \mathrm{~N}, \mathrm{~F}_{7}=$ Bio-fertilizer $+37.5 \mathrm{~N}, 1^{\text {st }}=1^{\text {st }} \operatorname{season}(2011 / 2012), 2^{\text {nd }}=2^{\text {nd }}$ season $(2012 / 2031)$ and $n . s=$ no significant.

Table (2): Effect of the interaction between wheat varieties and fertilizer treatments on yield and some yield traits in 2011/2012 and 2012/2013 seasons.

\begin{tabular}{|c|c|c|c|c|c|c|c|c|c|c|c|c|c|c|c|c|}
\hline \multirow[t]{2}{*}{ Fertilizer } & \multicolumn{2}{|c|}{\begin{tabular}{|c|}
$\begin{array}{c}\text { plant height } \\
(\mathrm{cm})\end{array}$ \\
\end{tabular}} & \multicolumn{2}{|c|}{$\begin{array}{c}\text { No. of } \\
\text { spike/plant }\end{array}$} & \multicolumn{2}{|c|}{\begin{tabular}{|c|}
$\begin{array}{c}\text { No. of grains } \\
\text { /spike }\end{array}$ \\
\end{tabular}} & \multicolumn{2}{|c|}{$\begin{array}{c}\text { Weight of } \\
\text { grains /spike }\end{array}$} & \multicolumn{2}{|c|}{$\begin{array}{c}\text { 1000-grains } \\
\text { weight (g) }\end{array}$} & \multicolumn{2}{|c|}{$\begin{array}{c}\text { Harvest } \\
\text { index }(\%)\end{array}$} & \multicolumn{2}{|c|}{$\begin{array}{c}\text { Grain yield } \\
\text { (ton/fed.) }\end{array}$} & \multicolumn{2}{|c|}{ Protein \% } \\
\hline & $\mathrm{V}_{1}$ & $\mathrm{~V}_{2}$ & $\mathrm{~V}_{1}$ & $\mathrm{~V}_{2}$ & $\mathrm{~V}_{1}$ & $\mathrm{~V}_{2}$ & $\mathrm{~V}_{1}$ & $\mathrm{~V}_{2}$ & $\mathrm{~V}_{1}$ & $\mathrm{~V}_{2}$ & $\mathrm{~V}_{1}$ & $\mathrm{~V}_{2}$ & $\mathrm{~V}_{1}$ & $\mathrm{~V}_{2}$ & $\mathrm{~V}_{1}$ & $\mathrm{~V}_{2}$ \\
\hline \multicolumn{17}{|c|}{$1^{\text {st }}$ Seasons $(2011 / 2012)$} \\
\hline $\mathbf{F}_{1}$ & 76.67 & 88.67 & 4.67 & 4.00 & 61.00 & 60.00 & 3.30 & 2.90 & \begin{tabular}{|l|}
46.17 \\
\end{tabular} & 47.40 & 36.57 & 35.81 & 1.70 & 2.15 & 7.57 & 7.49 \\
\hline $\mathbf{F}_{2}$ & 75.00 & 76.33 & 5.67 & 4.33 & 52.33 & 49.00 & 2.90 & 2.70 & 47.47 & 45.20 & 36.06 & 36.60 & 2.07 & 1.88 & 11.01 & 11.02 \\
\hline$F_{3}$ & 81.00 & 90.33 & 3.67 & 5.33 & 60.00 & 59.33 & 3.10 & 3.10 & 48.23 & 47.83 & 38.77 & 38.14 & 2.23 & 2.24 & 14.08 & 14.69 \\
\hline $\mathbf{F}_{4}$ & 77.00 & 86.67 & 5.00 & 5.33 & 62.67 & 64.00 & 2.47 & 3.10 & 46.13 & 44.97 & 37.53 & 37.05 & 1.55 & 1.81 & 14.03 & 14.27 \\
\hline $\mathbf{F}_{5}$ & 79.33 & 87.33 & 4.00 & 5.33 & 62.67 & 64.67 & 3.17 & 3.10 & 45.57 & 44.13 & 35.83 & 34.77 & 1.69 & 1.81 & 12.20 & 12.85 \\
\hline$F_{6}$ & 78.67 & 82.67 & 4.67 & 4.33 & 58.00 & 61.33 & 2.57 & 2.90 & 44.87 & 44.63 & 36.41 & 38.77 & 1.54 & 1.70 & 8.63 & 9.79 \\
\hline $\mathbf{F}_{7}$ & $\begin{array}{l}72.67 \\
\end{array}$ & 79.33 & 4.67 & 5.00 & 61.67 & 59.67 & 3.03 & 3.33 & 46.70 & 45.60 & 37.61 & 38.69 & 1.53 & 1.65 & 13.05 & 13.08 \\
\hline $\mathbf{L S D}_{0.05}$ for $\mathrm{V}^{*} \mathbf{F}$ & \multicolumn{2}{|c|}{ n.s } & \multicolumn{2}{|c|}{0.81} & \multicolumn{2}{|c|}{ n.s } & \multicolumn{2}{|c|}{0.30} & \multicolumn{2}{|c|}{ n.s } & \multicolumn{2}{|c|}{ n.s } & \multicolumn{2}{|c|}{0.24} & \multicolumn{2}{|c|}{0.56} \\
\hline \multicolumn{17}{|c|}{$2^{\text {nd }}$ Seasons $(2012 / 2013)$} \\
\hline$F_{1}$ & 86.33 & 85.00 & 5.67 & 4.67 & 64.33 & 61.33 & 3.17 & 2.80 & 46.70 & 47.73 & 48.00 & 43.20 & 2.52 & 2.66 & 7.55 & 7.51 \\
\hline $\mathbf{F}_{2}$ & 83.33 & 80.00 & 5.33 & 5.33 & 63.00 & 61.00 & 3.03 & 2.63 & 48.03 & 46.13 & 41.03 & 41.50 & 2.24 & 2.38 & 10.96 & 11.10 \\
\hline $\mathbf{F}_{3}$ & 89.33 & 88.33 & 5.00 & 5.00 & 64.00 & 58.00 & 3.17 & 2.97 & $\begin{array}{l}48.87 \\
\end{array}$ & 48.17 & 46.04 & 43.76 & 2.66 & 2.52 & 14.63 & 14.95 \\
\hline$F_{4}$ & 87.00 & 91.67 & 5.33 & 5.67 & 67.67 & 69.33 & 2.97 & 3.37 & 46.73 & 45.53 & 44.30 & 47.27 & 2.45 & 2.45 & 14.39 & 14.45 \\
\hline$F_{5}$ & 86.67 & 91.00 & 4.67 & 6.00 & 70.33 & 67.00 & 3.63 & 3.43 & 46.07 & 45.10 & 40.30 & 40.48 & 2.10 & 1.75 & 12.64 & 12.92 \\
\hline$F_{6}$ & 87.33 & 87.33 & 4.67 & 5.00 & 60.33 & 66.67 & 2.77 & 3.07 & 45.70 & 45.43 & 41.29 & 38.80 & 2.31 & 2.14 & 8.77 & 10.00 \\
\hline $\mathbf{F}_{7}$ & 81.67 & 87.67 & 5.00 & 4.67 & 57.67 & 66.33 & 2.70 & 3.33 & 47.00 & 46.20 & 46.66 & 44.01 & 2.80 & 2.31 & 13.00 & 13.20 \\
\hline $\mathrm{LSD}_{0.05}$ for $\mathrm{V}^{*} \mathbf{F}$ & \multicolumn{2}{|c|}{ n.s } & \multicolumn{2}{|c|}{0.87} & \multicolumn{2}{|c|}{4.29} & \multicolumn{2}{|c|}{0.31} & \multicolumn{2}{|c|}{ n.s } & \multicolumn{2}{|c|}{ n.s } & \multicolumn{2}{|c|}{ n.s } & \multicolumn{2}{|c|}{ n.s } \\
\hline
\end{tabular}

$F_{1}=$ Mineral fertilizer $75 \mathrm{~N}$ (Control), $F_{2}=$ Organic $30 \mathrm{~m}^{3}+$ Bio-fertilizer, $F_{3}=$ Organic $30 \mathrm{~m}^{3}+$ Bio- $^{-}$ fertilizer $+37.5 \mathrm{~N}, \mathrm{~F}_{4}=$ Organic $30 \mathrm{~m}^{3}+$ Bio-fertilizer $+18.75 \mathrm{~N}, \mathrm{~F}_{5}=$ Organic $30 \mathrm{~m}^{3}+37.5 \mathrm{~N}$, $F_{6}=$ Organic $15 \mathrm{~m}^{3}+37.5 \mathrm{~N}, \mathrm{~F}_{7}=$ Bio-fertilizer $+37.5 \mathrm{~N}, 1^{\text {st }}=1^{\text {st }} \operatorname{season}(2011 / 2012), 2^{\text {nd }}=2^{\text {nd }}$ season (2012/2031) and n.s $=$ no significant.

\section{Stepwise regression}

Stepwise regression is a semi-automated process of building a model by successively adding or removing variables based solely on the t-statistics of their estimated coefficients. In order to remove effect of non-effective characteristics in regression model on grain yield, stepwise regression was used. Results of stepwise regression (Table 3) showed that the harvest index

Fayoum J. Agric. Res. \& Dev., Vol. 31, No.2, July, 2017 
Abd El-Samie, F.S.,

(HI), 1000 grains weight (SI), number of grains/ spike (NGS) and plant height (PLH) with R square of $69.35 \%$, had justified the maximum of yield changes. Therefore the following equation can be obtained: 0.008PLH

Grain yield $(\mathrm{GY})=-2.049+0.071 \mathrm{HI}+0.029 \mathrm{SI}-0.012 \mathrm{NG}+$

Existence of significant $\mathrm{R}$ square in a successful regression equation indicates the effectiveness of these traits to increase grain yield. Leilah and AlKhateeb (2005), Ahmadizadeh et al. (2011) and Zarei et al. (2011) reported importance of Harvest index to grain yield. However, obtained results were in the opposite of those of Soleymanifard et al. (2012), who found that $75 \%$ of variation in grain yield is explained by 1000 grain weight and plant height traits. With respect to the positive and significant regression coefficients of harvest index, it could be stated that increasing the amount of these traits will cause an increase in the yield. Thus, in this study, harvest index trait had the most effect on the grain performance in newly reclaimed soil.

Table (3): Regression coefficient, standard error, t-value and probability of the accepted variables by the stepwise procedure to predict grain yield.

\begin{tabular}{|c|c|c|c|c|c|c|}
\hline Traits or variable & B & SE & t & Sig & VIF & $\mathbf{R}^{\mathbf{2}}$ \\
\hline Plant height & 0.008 & 0.004 & 1.880 & 0.064 & 1.200 & $1.37 \%$ \\
\hline No. of grains /spike & -0.012 & 0.006 & -2.020 & 0.047 & 1.230 & $0.91 \%$ \\
\hline 1000-grains weight & 0.029 & 0.011 & 2.590 & 0.011 & 1.070 & $3.20 \%$ \\
\hline Harvest index & 0.071 & 0.006 & 11.110 & 0.000 & 1.230 & $63.87 \%$ \\
\hline
\end{tabular}

B: Regression coefficient, SE: Standard error, $t$ : Student t-value and Sig: Probability. $\mathbf{R}^{2}$ $=69.35 \%$, Adj $R^{2}=67.80 \%$, Predicted $R^{2}=65.83 \%$ and Constant $=\mathbf{- 2 . 0 4 9}$.

\section{REFERENCES}

Abd El - Razek , U . A . and A . A . El Sheshtawy ( 2013) . Response of some wheat varieties to Bio and mineral nitrogen fertilizers . Asian Journal of Crop Science: $1-9$.

Abo - Remaila, S. I. and M. M. Abou El Enin( 2016 ). Effect of applying Potassumage and Banana ash combination as bio fertilizers on productivity Of the Egyptian wheat. Journal of Basic and Environmental Sciences 3 : $98-106$.

Abraham , T. and R. B. Lal (2004).Effect of integrated nutrient management on productivity of wheat (|Triticum aestivum L.) And soil fertility in a legume based cropping system . Indian J. Agric. Res., 38 (3) : 178 - 183.

Ahmadizadeh, M. A. Nori, H. Shahbazi, and S. Aharizad (2011). Correlated response of morpho-physiological traits of grain yield in durum wheat under normal irrigation and drought stress conditions in greenhouse. African Journal of Biotechnology, 10 (85): 19771 19779.

Fayoum J. Agric. Res. \& Dev., Vol. 31, No.2, July, 2017 
WHEAT PRODUCTIVITY AS AFFECTED BY.

Agamy, R. A., G . F . Mohamed and M. M. Rady ( 2012). Influence of the Application of Fertilizer Type on Growth, Yield, Anatomical Structure and Some Chemical Components of Wheat ( Triticum aestivum L.) Growth in Newly Reclaimed Soil . Australian Journal of Basic and Applied Sciences, 6(3 ) : $561-570$.

Ali, G. A. , O. E. Zeiton , A. H. Bassiouny and A. R. Y. A. El-Banna ( 2004 ). Productivity of wheat cultivars grown at El-Khattara and ElArish under different levels of planting densities and $\mathrm{N}$ fertilization. Zagazig J. Agric. Res. 31(4A) : 1225 - 1256.

Babar, A. A. , M. A. Ansari, G. M. Laghari, A. A. Soomro and M. N. Kandhro (2016) . Effect of Macro-Nutrient and Humic Acid on Growth and Yield of Different Wheat Genotypes . Sci. Int. (Lahore) , 28(3), 2655 -2660.

Badran, M. S. S.( 2009). Improving wheat productivity by bio-nitrogen fertilization under newly planted sandy soils. J. Agric. Sci. Mansoura Univ. 34 (3): 1781- 1795.

Bithy, N. A. ( 2014 ). Effect of Variety and Fertilizer Management on the Performance of Wheat. M. Sc. Thesis, Fac. Agric. Bangladesh Agricultural Univ.

El - Gizawy , N. Kh . B . ( 2009 ). Effect of Planting Date and Fertilizer Application on Yield of Wheat Under No Tillage System . World J . Agric. Sci. , 5 ( 6 ) : 777 - 783 .

El-Nady , M. A. and T. I. Borham ( 2013 ). Influence of Different Tillage Systems and Fertilization Regimes on Wheat Yield, Wheat Components and Water Use Efficiency .Egypt. J. Soil Sci. ,53 ( 4 ), pp. $579-593$.

Esmailpour , A ., M . Hassanzadehdeloueiand A . Madani ( 2013) .Impact of Livestock Manure, Nitrogen and bio - fertilizer ( Azotobacter) on Yield and Yield Components of Wheat( Triticum aestivum L . ) . Cercetari Agronomic in Moldova, XL V1 (2) ( 154$) /: 5-15$.

FAO ( Food and Agriculture Organization of the United Nations ), 2013. FAOSTAT : World Crop Production data . Accessed on 23 March , 2014 . Available at : ( http : // www. faostst . fao. org / site ).

Granland , M . and D . C . Zimmerman ( 1975 ) . Oil Content of Sunflower Seed as Determined by Wide Line Nuclear Magnetic Resonance. Acad. Sci., 27 : 123 - 133 .

Hammad , H. M., Abdul Khaliq , A. Ahmad , M. Aslam , A. H. Malik , W. Farhad and K. Q. Laghari ( 2011). Influence of Different Organic Manures on Wheat Productivity. Int. J. Agri. Biol., $13: 137-140$.

Fayoum J. Agric. Res. \& Dev., Vol. 31, No.2, July, 2017 
Abd El-Samie, F.S.,

Leilah A.A. and S. A. Al-Khateeb (2005). Statistical analysis of wheat yield under drought conditions, Journal of Arid Environments, 61 (3): 483 $-496$.

Lemma , E. ( 2015 ). Effect of blended fertilizers on yield and yield traits of durum wheat (Triticum Turgiduml. Var. Durum) varietiesinada district, central Ethiopia . M. Sc. Thesis , fac. Agric. Haramaya Univ.

Mattas , K . K . , R . S . Uppal and R . P . Singh (2011) . Effect of Varieties and Nitrogen Management on the Growth, Yield and Nitrogen Uptake of Durum Wheat. Res. J . Agric. Sci., 2 ( 2 ) : $376-$ 380 .

Mehasen , S. A. S. , S. A. Badawy and S. Sh. Abdullah ( 2015 ) . Influence of bio and mineral nitrogen fertilizers on productivity of some bread wheat varieties . Journal of Food, Agriculture \&Environment , 13 (2) :162 - 167 .

Mohamed, N.A., (1999). Some statistical procedures for evaluation of the relative contribution for yield components in wheat. Zagazig Journal of Agricultural Research, 26 (2): 281 - 290

Mohammad, S . S . , A . G . Osman , A . M . Mohammed , A . S . Abd alla , A . M. Sherif and A . M . E . Rugheim (2012). Effects of Organic and Microbial Fertilization on Wheat Growth and yield. Int. Res. J . Agric. Sci. and Soil Sci. , 2 ( 4 ), PP. 149 $-154$.

Pržulj, N. and V. Momcilovic (2011). Characterization of vegetative and grain filling periods of winter wheat by stepwise regression procedure. I. Vegetative period. GENETIKA, 43 (2): 349 - 359.

Radwan, F.I. , M.A. Gomaa, M.A.A. Naser and I. F. Mussa ( 2014 ). Response of some Wheat Varieties to Humic Acid, Mineral and Bio- fertilization on Productivity and Quality . Middle East Journal of Agriculture Research , 3 (3) : 631 - 637.

Shah , S. A ., S . M. Shah , W. Mohammad , M . Shafi , H. A. Q Nawaz , S. S. Zadi and M.Amir ( 2010 ) . Effect of Integrated Use of Organic and Inorganic Nitrogen Sources on Wheat Yield. Sarhad J. Agri., 26 ( 4 ) : 559 - 563 .

Snedecor, G . A . and A. D . Cochran ( 1980 ). Statistical Methods $7^{\text {th }}$ Edition , Iowa State Univ.

Soleymanifard, A., Naseri, R. and, M. Meysam(2012). The study genetic variation and factor analysis for agronomic traits of Durum wheat genotypes using cluster analysis and path analysis under drought stress condition in western of Iran. Intl. Res. J. Appl. Basic. Sci., 3 (3): $479-485$.

Steel , R. G . D . and J . H . Torrie ( 1960 ). Principles and Procedures of Statistics. McGraw Hill Book Co. Inc. New York.

Fayoum J. Agric. Res. \& Dev., Vol. 31, No.2, July, 2017 
WHEAT PRODUCTIVITY AS AFFECTED BY.

Wallace , D. J. , J. L. Ozbarn and H. M. Munger ( 1972 ) .Physiological genetics of crop yield . Adv. Agron. , 24: 92 -146 . ( cited after Sinha, S.K. , FAO Consultant , FAO ,Viadelle Temedi Caracalla , 00100 Rome, Italy ).

Woyema, A ., G . Bultosa and A. Taa ( 2012). Effect of Different Nitrogen Fertilizer Rates on Yield and Yield Related Traits for Seven Durum Wheat ( Triticum Turgidum L. Var Durum ) Cultivars Grown at Sinana, south Eastern Ethiopia . African J . of Food, Agri., Nutrition and Development, 12(3), : $6079-$ 6094 .

Zaki, N . M ., M . A . Gomaa, F . I . Radwan, M . S . Hassanein and A . M. Wali ( 2012 ). Effect of Mineral, Organic and Bio Fertilizers on Yield, Yield Components and Chemical Composition of Some Wheat Cultivars . J . Appl. Sci. Res., 8 (1) : $174-191$.

Zarei, L., K. Cheghamirza, and E. Farshadfar (2011). Interrelationships of some agronomic characters of durum wheat under supplementary irrigation at grain filling stage conditions. Researches of the first international conference. (Babylon and Razi Universities) 2011, 9. 211-215.

Fayoum J. Agric. Res. \& Dev., Vol. 31, No.2, July, 2017 
تاثير الاصناف والتسميل المعدي والعضوي علي انتاجية محصول القـح تحت ظروف الار اضي

أ.د فوزي سيد عبدالسميع، أ.د اكرام علي مجاور، د. سمير كامل علي، م. أحمد حافظ ربيع

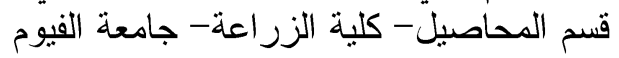

أقيمت تجربتان حقليتان بمزرعة كلية الزراعة - جامعة الفيوم - بمنطقة دمو - محافظة

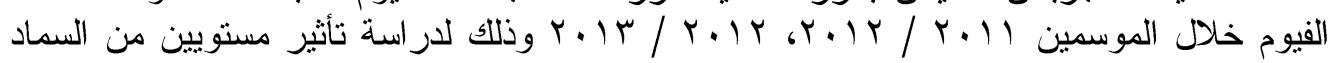

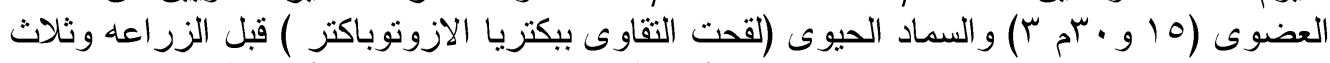

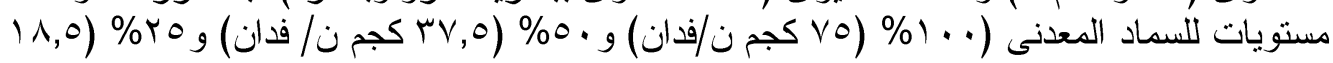

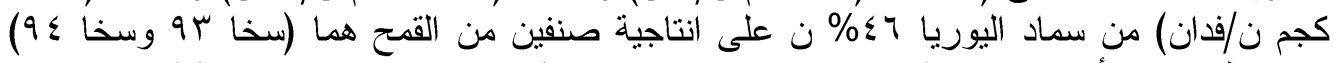

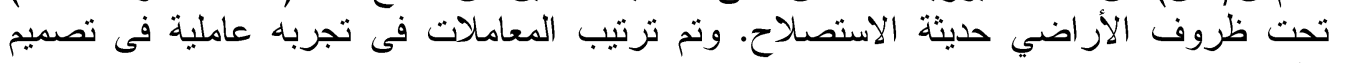

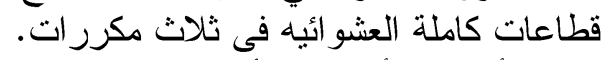

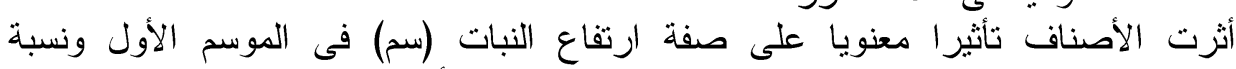

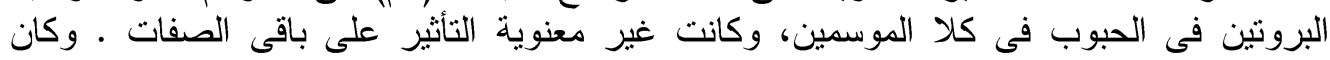

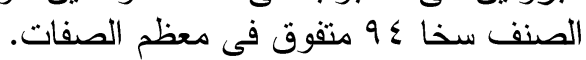

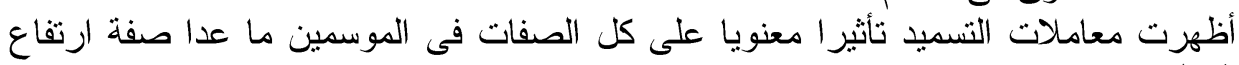

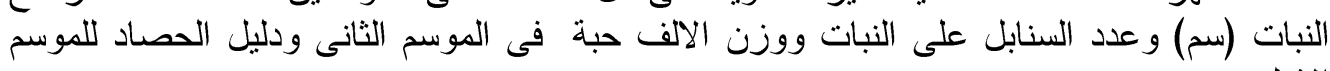

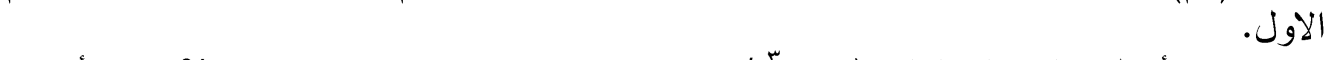

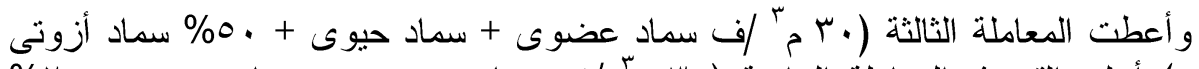

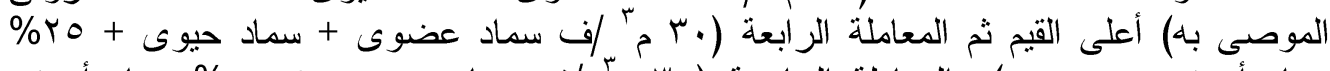

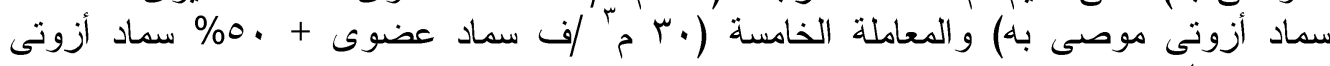

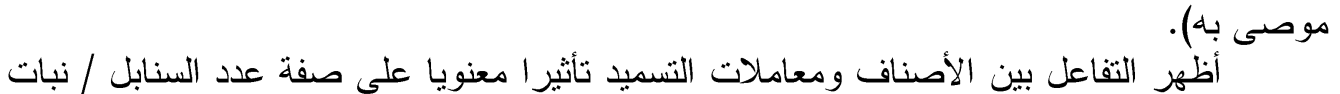

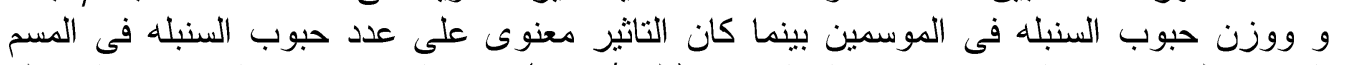

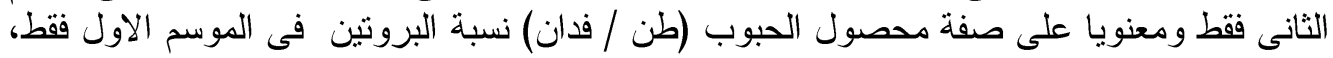

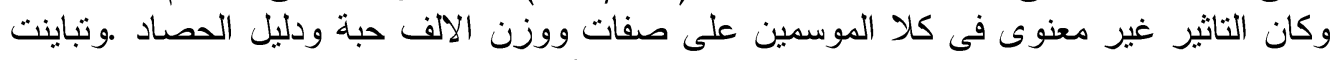

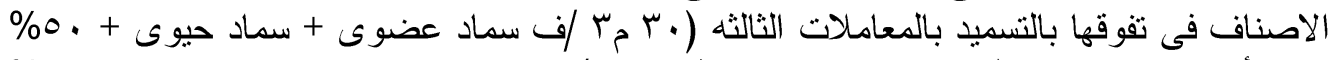

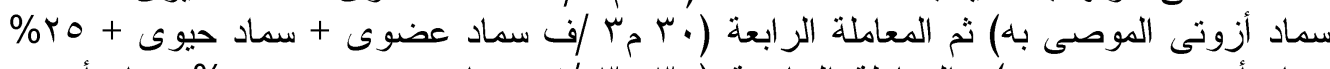

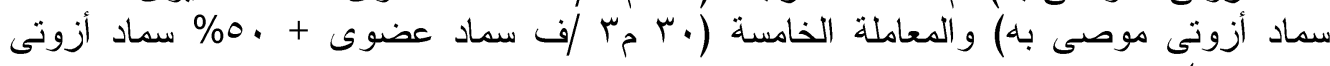
موصى به).

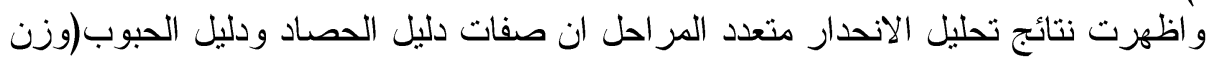

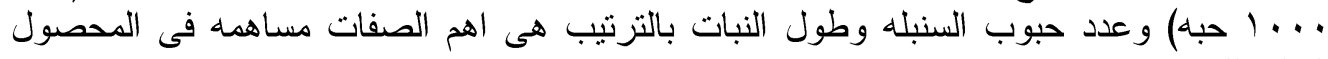

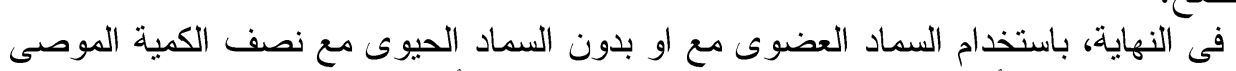
العالى للقمح.

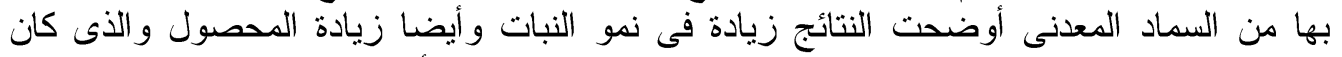

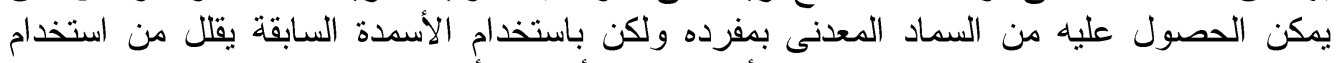

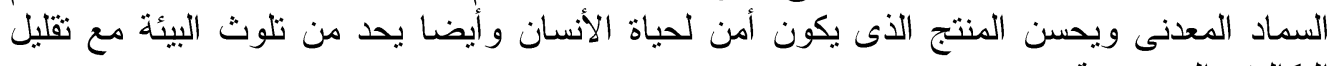
التكاليف المستخدمة.

Fayoum J. Agric. Res. \& Dev., Vol. 31, No.2, July, 2017 